\title{
Reversing Breast Cancer in a Premenopausal Woman: A Case for Phyto-Nutritional Therapy
}

\author{
Steve Yap
}

DSY Wellness and Longevity Center, Kuala Lumpur, Malaysia

\begin{abstract}
Globally, breast cancer incidence increases at $1 \%$ to $2 \%$ annually. It is the number one cause of cancer death in women. Current literature implies that soy food intake is linked to decreased risk of breast cancer due to its rich isoflavones. On the other hand, intake of animal fat, red meat, organ meat and high-fat dairy products during premenopausal years may increase risk for this cancer, but no apparent risk has been established for fish or poultry intake. Monounsaturated fat and the improved ratio of omega- 3 to omega- 6 fatty acids have showed potential to reduce risk. On the other hand, high glycemic index diet but not glycemic load is associated with a significantly increased risk. Central rather than general obesity carries similar risk. Furthermore, lifestyle rather than genetic differences are widely implicated in breast cancer. A comprehensive phyto-nutritional therapy was adopted for treating a case involving stage IV breast cancer in a premenopausal woman, who was turned away by a hospital offering conventional treatment. The therapy involved designing and monitoring the implementation of dietary plans to achieve optimum health outcomes for the major abnormal metabolic blood/urine markers identified for this particular patient. Nutrient-dense food items with generous servings of a variety of spices and herbs, supplemented by vitamins, minerals and phyto-extracts was prescribed as part of the therapy. Many non-toxic dietary nutrients and phytonutrients are known cytotoxic agents promoting cancer regression via apoptosis pathways, which have yet to be fully understood. Conclusion: The complete remission of the malignancy initiated by this natural therapy would suggest that an advanced stage breast cancer is a metabolic disorder reversible by an evidence-based phyto-nutritional therapy. While not all cases of malignancy can possibly be completely reversed, the positive outcome achieved in partnership with the patient warrants further study involving larger number of women with similar level of malignancy.
\end{abstract}

Keywords: Breast cancer, nutritional therapy, dietary modification, nutraceuticals, apoptosis.

\section{CASE INTRODUCTION}

Kim T., age 48 and single mother to a 11-year old boy, worked as an accounts supervisor in a major hardware retail chain in Kuala Lumpur, Malaysia. After several lymph nodes in both her arm pits and neck began to swell, she admitted herself into a governmentfunded hospital. Her computed tomography (CT) scans detected extensive lumps on her left breast and a few much smaller lumps on her right breast. Biopsy results confirmed her worst fear: she was suffering from stage IV breast cancer. Her emotional state was made worse after being told by the hospital oncologist that "there wasn't much point in trying to treat such a late stage cancer." Despite such grim diagnosis, she returned to work after a week's rest in order to financially support her child and mother.

Although she disliked alcohol, she was fond of having a carbonated drink for her lunch. Breakfast would usually consist of noodles, oat porridge, toasted white bread with fruit jam and/or margarine, puffed cereals with long-life milk, packaged fruit juice and/or a sweetened beverage. Biscuits, cookies, buns, cakes, or pastries with sweetened coffee or tea were provided by her employer during the late afternoon. Dinner was

*Address correspondence to this author at the DSY Wellness and Longevity Center, Kuala Lumpur, Malaysia; Tel: +60342701266; Fax: +60342701831; E-mail: dsy@dsywellness.com usually served at home. Her live-in mother helped to care for her over-weight child, who received just 2 months' of breastfeeding. The family was fond of deepfried foods and noodles. For convenience, canned food was often served after being microwaved. Fresh vegetables were purchased once a week and served two or three times weekly.

For the past decade prior to cancer diagnosis she was suffering from insomnia, frequent flu infection, body aches, and weight gain. Her body mass index (BMI) was 30.2, which put her in the obese category. Total fat mass was $37.3 \%$, visceral fat was $21 \%$, and total body water was at a low of $41.6 \%$. Serum triglyceride levels tested over the past three years were in excess of $350 \mathrm{mg} / \mathrm{dl}$. She attributed her poor physical health to long working hours in a company competing fiercely in markets affected by economic recession. Having to work on most Saturdays meant little time for any outdoor or physical activity. Preliminary test results from the hospital indicated the presence of an estrogen-responsive MCF-7 breast cancer cell line.

\section{DIETARY/NUTRITIONAL RECOMMENDATIONS}

Recognizing that dietary modifications could prevent more than two-thirds of cancers [1], the recommendations to the patient included: 


\subsection{Increase Intake of Dietary Fiber}

Low fiber intake could lead to larger tumor size [2] and fiber can reduce incidence of breast cancer (BC) [3]. Consumption of total dietary fiber from fresh vegetables and citric fruits - but not from cereal - is found to be inversely associated with BC risk [4]. A very low fat, high fiber diet in premenopausal women could reduce their tumor/cancer promoting estradiol levels without affecting ovulation [5]. Flaxseed lignin could similarly reduce risk [6] and supplemented lignan might significantly improve glycemic control as evidenced by lower $\mathrm{HbA} 1 \mathrm{c}$ and lower C-reactive protein (CRP) levels in type 2 diabetes patients $[7,8]$.

\subsection{Fresh Organic Berries and Fruits}

Nutritional intake provided by freshly harvested organic vegetables and fruits has a direct positive relationship with survival [9]. Fisetin $\left(3,3^{\prime}, 4^{\prime}, 7-\right.$ tetrahydroxyflavone), a flavonoid found in fruits such as cucumbers, kiwifruit, persimmons, and grapes, can induce higher cytotoxicity in BC cells with apparently no cytotoxicity in non-tumorigenic cells [10]. Apigenin inhibits tumor angiogenesis through reducing expression of the vascular endothelial growth factor (VEGF) in tumor cells [11, 12]. This flavonoid found in local guava and bell pepper is known to inhibit tumor metastasis [13].

\subsection{Soy Food in Place of Animal Products}

Soy intake seems to be associated with longer survival and low recurrence among BC patients [14, 15]. High intake is inversely associated with $B C$ risk $[16,17]$. Frequent intake of tofu reduces risk of this cancer in both pre- and postmenopausal women after adjustment for their age, study area, and ethnicity [18]. The protective effect of soy food, soy isolate, or soy protein does not seem to matter if the $B C$ is estrogen receptor positive $(E R+)$ or otherwise [19]. In raising serum concentrations, genistein in soy food seems to be as helpful as those found in supplements [20]. Genistein can offer substantial clinical benefit to patients with various types of cancer. Declining estrogen receptor-beta (ER-beta) expression can promote progression in breast malignancy. Genistein has a very much higher affinity to ER-beta than to ERalpha, which is over-expressed in most breast cancer cases. Patient was advised to take only soy products from non-genetically modified or organic sources.

\subsection{Fresh Organic Vegetables}

Cruciferous such as cabbages and broccoli contain indole-3-carbinol (I3C) which not only prevents BC [21], but also possesses anti-cancer properties [22]. I3C strongly down-regulates ER-alpha proteins [23]. Following molecular transformation of I3C by stomach acid, DIM (3,3'-Diindolylmethane) is generated. DIM is known to induce apoptosis in breast [24] and various other cancer cell lines. Sulforaphane, an isothiocyanate also found in cruciferous vegetables and is especially high in broccoli sprouts [25], can inhibit tumor cell growth besides activating apoptosis and decreasing over-expression of survivin which is involved in BC cell proliferation [26]. Apigenin possesses anti-tumor properties and its content in Chinese cabbage is $187 \mathrm{mg} / \mathrm{kg}$. Luteolin in broccoli is about $74 \mathrm{mg} / \mathrm{kg}$ of its dry weight [27]. This phytonutrient could induce apoptosis through insulin growth factor-1 (IGF-1) receptor signaling while inhibiting cancer metastasis via the protein epithelial cadherin [28, 29], which may be used as a diagnostic biomarker in BC [30]. Green leafy vegetables are rich in folate, which higher plasma levels are linked to reduced risk of developing BC [31, 32].

\subsection{Generous Serving of Spices}

Fenugreek (Trigonella foenum-graecum) as a spice may hold promise in treating $\mathrm{BC}$ [33]. Its diosgenin, a steroid saponin considered safe even at very high doses [34], suppresses the proliferation of BC cell lines [35]. It can destroy tumor cells through induction of apoptosis [33]. Fisetin, a flavonoid found in onion and garlic, activates the cancer protective p53 gene and the fisetin-induced apoptosis seems unaffected by the p53 inhibitor pifithrin-alpha [10]. Garlic contains apigenin too. Capsaicin, a biologically active ingredient in the red chili [36], may retard proliferation of cancer cells by suppressing their inflammatory response, and may mediate apoptosis through the beta-catenin pathway, which is corrupted in many cancers [37, 38]. Black pepper's resin contains piperine, which enhances absorption of green tea polyphenols and curcumin [39]. Ginger contains 6-gingerol [40], which has pronounced anti-inflammatory activity [41] and can inhibit invasion, motility, and adhesion in BC cell lines [42], besides treating nausea and vomiting [43].

\subsection{Sweet Potato, Pumpkin, and Carrot}

These alpha-carotene rich foods may be helpful to women with invasive BC with nodal metastasis [44] while their beta carotene content can significantly 
improve patient's survival [45]. Generally, carotenoids are known to be BC protective [46].

\subsection{Fatty Fish}

Women having high intake of eicosapentaenoic acid (EPA) enjoy significant reduction in BC risk [47-50]. A higher intake of omega-3 (n-3) fatty acids can decrease both inflammation and physical aspects of fatigue [51]. Docosahexaenoic acid (DHA) rather than EPA seems to be a stronger anti-neoplastic agent [52]. Adequate intake of n-3 fatty acid can reverse loss of critical adipose tissue [53] and can promote gain in lean body mass [54]. Fish rich in EPA/DHA fats include anchovy, mackerel, cod, and wild salmon.

\subsection{Tryptophan-Rich Diet}

Since many BC patients experience depression, anxiety, insomnia and cognitive dysfunction [55], a tryptophan-rich diet helps to reduce sleep disturbances [56]. Amino-acid L-tryptophan in soy isolate, organic lean poultry, leafy vegetables, legumes, and seeds is converted into brain neurotransmitter serotonin via L-5hydroxytryptophan (5-HTP). The pineal gland then converts serotonin to the antioxidant hormone melatonin [57], which does not raise BC markers such as circulating estradiol and IGF-1 [58]. Quality sleep promoted by adequate melatonin secretion actually lowers risk of BC [59] and enhances the patient's chances of survival [60].

\subsection{Nuts, Seeds and Beans}

These are rich in vitamin E, which can inhibit cancer cell proliferation [61]. Selenium deficiency increases the risk of cancer [62] and is associated with a higher risk of fatal cancer [63]. Brazil nuts, for instance, may contain as much as 544 micrograms of selenium per ounce [64]. Consequently, two Brazil nuts can provide some $200 \mathrm{mcg}$ selenium sufficient to lower this cancer risk [65] while offering possibly up to $50 \%$ reduced risk of cancer death [66]

\section{Cooking and Food Preparation Methods}

Deep frying, double-boiling, barbequing, microwave cooking or sauteed of food was not recommended due to possibly increased carcinogenic agents. Frying, for instance, can destroy up to $32 \%$ of a key nutrient Coenzyme Q10 in food, but no detectable destruction when boiling method is used [67]. Less-refined Malaysian palm fruit oil was recommended for cooking since its rich source of carotenoids, tocotrienols and tocopherols may have anti-tumor properties [68].

\section{Beverages}

(i) Green tea (Camellia sinensis): two or more cups a day, but not in the evening. It contains catechins, which can kill BC estrogen-responsive MCF7 cells through induction of apoptosis effected by its ability to increase the expression of pro-apoptotic genes such as caspase-3, -8, and -9 and TP53 [69].

(ii) Artemisia annua tea: two to three cups a day of grounded leaf, which is widely available in Malaysia. Its active polyphenol, artemisinin, can arrest tumorigenic BC cell lines including late stage cancer phenotypes [70]. Treatment of MCF7 cells with artemisinin can block estrogenstimulated cell cycle progression induced by 17beta-estradiol, an agonist for both types of estrogen receptor [71].

(iii) Malaysian Cocoa: two to three cups a day, one tablespoon each. It is rich in trans-resveratrol that can affect multiple intracellular signaling transduction pathways such as p53 activation, protein translation inhibition, and apoptosis in a dose-dependent manner [72]. Resveratrol is known to induce growth inhibition and apoptosis even in highly invasive and metastatic BC cell line [73].

The patient was advised to avoid:

\section{(i) High Fat Dairy Products}

Cow milk may contain traces of hormones including IGF-1. However, in pre-menopausal women the consumption of dairy products, especially of low-fat dairy foods and skim/low-fat milk, may be inversely associated with risk of BC [74].

\section{(ii) Refined Sugars, Starches, High Fructose Drinks}

Cancer or tumor cells are primarily sugar metabolizers [75] in an anaerobic environment. Hyperglycemia raises the pro-inflammatory process and adversely affects the patient's immune system [76].

\section{(iii) High Fat Diet}

Higher intake of omega- $6(n-6)$ relative to $n-3$ fatty acids is associated with greater C-reactive protein score and greater odds of fatigue [51]. Women with lower intake of marine-derived $\mathrm{n}-3$ fats and higher intake of $n-6$ fats can suffer higher risk for BC [77]. 
(iv) Meat from Farmed Animal, Livestock or Fish

While meat from grass-fed cattle and from freerange livestock may be rich in $\mathrm{n}-3$ fatty acids [78], that from farmed animal/livestock/fish tends to be higher in pro-inflammatory $n-6$ fats.

\section{(v) Eel, Red and Organ Meat}

While iron deficiency anemia can independently increase morbidity and mortality [79], elevated ferritin (stored iron) levels are associated with a higher risk of diabetes independent of inflammatory markers and metabolic syndrome [80]. There seem to be a higher mortality at high levels of consumption of egg yolks and red meats [45]. However, strong tea or coffee can block or reduce absorption of iron [81]. Tissue ferritin from mammary carcinomas have showed up to $1000 \%$ higher than benign breast tissues [82]. Iron overload can lead to oxidative stress mediated by highly reactive oxygen species including hydroxyl radicals known to promote mutagenesis, DNA strand breaks, activation of oncogenes, and tumor suppressor gene inhibition [83]. Consequently, iron chelators are being investigated as cancer therapeutics [84]. The patient lowered her serum ferritin by some $54 \%$ during the six-month therapy, while her lowered $\mathrm{HbA1c}$ scores suggested a return to normal blood glucose levels within the same period (Table 1).

\section{Nutraceuticals}

Nutritional supplements could improve overall micronutrient intakes of BC patients or survivors [83, 85]. The following nutraceuticals were prescribed to be taken with or after meals:

\subsection{Co-enzymeQ10}

$200 \mathrm{mg}$ twice a day (BID). Three months intake has been showed to significantly improve clinical conditions besides regressing tumor [84] and a six months' intake may cause breast tumor to disappear [85]. $100 \mathrm{mg}$ for three months is known to reduce markers such as Carcino-embryonic antigen (CEA) and CA-153 [86]. Statins which the patient took over the years reduced her serum coenzyme Q10 levels [87-89].

\subsection{Vitamin D3}

4,000 IU thrice a day (TID). Serum 25(OH)D levels of about 75 to $110 \mathrm{nmol} / \mathrm{l}$ provide optimal benefits without increasing health risks and these levels can best be achieved by oral doses of at least 4,000 IU vitamin D3 per day [90]. A significantly higher risk of breast and other cancers may be linked to low serum $25(\mathrm{OH}) \mathrm{D}$ levels [91]. This nutrient has chemopreventive effects against BC [92]. The association of vitamin $D$ receptor polymorphisms and cancer risk seems strongest for BC [93] and supplemented vitamin D3 is not associated with any risk of BC [94]. The patient's serum $25(\mathrm{OH}) \mathrm{D}$ levels rose from a very low of 21 to $124 \mathrm{nmol} / \mathrm{l}$ at end of six months (Table 1). Besides, her health would have benefited in other ways since plasma $25(\mathrm{OH}) \mathrm{D}$ level is inversely associated with increased risk of metabolic syndrome and insulin resistance [95].

\subsection{Malaysian Wild bee Propolis, Wax Free}

20 drops in a cup of warm water TID. Its biologically active caffeic acid phenethyl ester (CAPE) possesses

Table 1: Extracts from Last Six Month Blood Test Results for 2013 and 2014

\begin{tabular}{|c|c|c|c|c|c|c|c|}
\hline Serum Markers & Aug & Sept & Oct & Nov & Dec & Jan & Feb \\
\hline CA15-3 $(<35 \mathrm{U} / \mathrm{ml})$ & 179 & 124 & 76 & 71 & 46 & 23 & 14 \\
\hline CEA (<5.0 ng/ml) & 52 & 46 & 35 & 30 & 14 & 6 & 3 \\
\hline hs-CRP (<1.0 mg/L) & 51 & 29 & 18 & 15 & 11 & 7 & 4 \\
\hline IL-6 (<5.9 pg/ml) & 136 & 104 & 86 & 77 & 49 & 32 & 19 \\
\hline $\mathrm{HbA1C}(</=5 \%)$ & 6.3 & 6.0 & 5.9 & 5.7 & 5.6 & 5.6 & 5.3 \\
\hline IGF-1 (103-291 ng/mL) & 216 & 197 & 175 & 169 & 170 & 164 & 155 \\
\hline Estradiol $(20-100 \mathrm{pg} / \mathrm{ml})$ & 167 & 152 & 125 & 87 & 89 & 68 & 67 \\
\hline Cortisol $(50-230 \mathrm{ng} / \mathrm{ml})$ & 225 & 187 & 155 & 129 & 98 & 87 & 89 \\
\hline $25-(\mathrm{OH}) \mathrm{D}(75-110 \mathrm{nmol} / \mathrm{l})$ & 21 & 36 & 53 & 76 & 87 & 105 & 124 \\
\hline Ferritin (20-300 ug/L) & 364 & 331 & 287 & 286 & 254 & 225 & 165 \\
\hline \multicolumn{8}{|l|}{ Physical data: } \\
\hline BMI & 30.2 & 28.1 & 27.6 & 26.9 & 24.6 & 24.1 & 23.7 \\
\hline
\end{tabular}


anti-mitogenic, anti-carcinogenic, anti-inflammatory and immunomodulatory properties [96]. It is a potent inhibitor of NFkB activation and it induces apoptosis via Fas signal activation in breast cancer MCF-7 cells [97] and through the caspase pathway [98] as well as interfering with tumor metabolic pathways [99]. Its antiproliferative effects in cancer cells are the result of suppressing complexes of cyclins and of cell cycle arrest [100].

\subsection{Ginseng Extracts (Standardized to $80 \%$ Ginsenosides)}

400mg TID. While its Rg3 component can inhibit breast and other tumor metastasis [101], its Rh2 component can induce apoptosis [102]. Furthermore, ginsenoside $\mathrm{F} 2$ induces apoptosis in BC cells by activating the intrinsic apoptotic pathway and mitochondrial dysfunction [103].

\subsection{Quercetin (with $30 \%$ Bromelain)}

$1 \mathrm{~g}$ TID. Quercetin inhibits cells proliferation, induces cell cycle arrest and apoptosis in breast MCF-7 and other cancer cell types [104] via mitochondrial- and caspase-3-dependent pathways [105]. It increases the pro-apoptotic protein Bax and decreases the levels of anti-apoptotic protein Bcl-2.

\subsection{Mixed Tocotrienols}

$300 \mathrm{mg}$ (450IU) BID. These members of the vitamin E family may inhibit proliferation of $B C$ cells by as much as $50 \%$ [106].

\subsection{Pomegranate Extract (Standardized to $40 \%$ Ellagic Acid)}

500mg TID. Ellagic acid induces apoptosis by suppressing inhibitor of the apoptosis protein survivin [107]. Besides inhibiting growth of the BC cells, ellagic acid with its other phytonutrients such as luteolin and punicic acid can decrease BC cell migration without adversely affecting normal cells [108].

\subsection{Beta-Carotene}

$500 \mathrm{mg}$ TID. Higher intake of this nutrient can result in significantly fewer deaths from BC $[45,109,110]$.

\subsection{Selenium Yeast}

$230 \mathrm{mg}$ BID (equivalent to $200 \mathrm{mcg}$ elemental selenomethionine). Increasing serum selenium levels of up to $130 \mathrm{ng} / \mathrm{mL}$ may decrease cancer mortality
[111]. Studies have showed that BC patients tend to have low serum selenium levels [112-114]. However its anti-carcinogenic effects may be neutralized by heavy metals such as lead, arsenic, and cadmium $[115,116]$.

\subsection{Vitamin B12}

$250 \mathrm{mcg}$ TID. Women with the highest levels of this vitamin intake may reduce risk of BC by some $68 \%$ [117]. Generally, vitamin antioxidants offer protective effects against BC [118]. Women who consume them may reduce their mortality risk by $18 \%$ and reduce their recurrence cancer risk by $22 \%$ [119].

Chronic inflammation is linked to increased risk of BC [120] and nutraceuticals inhibiting cyclooxygenase2 (COX-2) (enzyme that makes prostaglandins that cause inflammation) to block metastasis include curcumin, resveratrol and epigallocatechin gallate (EGCG) [121-124]. Other nutraceuticals with broadly similar properties include capsaicin, eugenol, and gingerol [125]. Consequently, these anti-inflammatory nutraceuticals were also prescribed:

\subsection{Curcumin (with $2 \%$ Piperine)}

$1 \mathrm{~g}$ TID after meal. Curcumin from Curcuma longa possesses strong anti-inflammatory and antioxidant properties [126] and exerts multiple suppressive effects in breast carcinoma cells [127]. Among the proteins it modulates include COX-2, VEGF (a chemical signal produced by cells that stimulates the growth of new blood vessels), the chemokines monocyte chemoattractant protein-1(MCP-1) and MCP-4, the interleukins IL-1 and IL-6, and insulin growth factor (IGF) [123, 128-131]. Piperine enhances the uptake and bioavailability of not just curcumin, but also the CoenzymeQ10 and tea polyphenols [39] for which the patient was prescribed. Curcumin with piperine have been showed to target destruction of BC stem cells (BSCs) [102]. They can inhibit mammosphere (large, floating spheres which is a hallmark feature of breast BSCs) formation [132] and chelate excess serum iron [133].

\subsection{Trans-Resveratrol (RSVL;3,4',5-Trihydroxy- stilbene) (Standardized to $20 \%$ )}

$400 \mathrm{mg}$ TID. This polyphenol can inhibit both COX-1 and COX-2 and its properties are comparable to nonsteroidal anti-inflammatory drugs [134]. Patient's inflammatory markers such as hs-CRP and IL-6 improved significantly by taking multiple antiinflammatory supplements as evidenced by her 
markers (Table 1) and wound appearance (Figure 1). Furthermore, resveratrol inhibits cancer metastasis by decreasing activity of matrix metallopeptidase 9 (MMP9) [135]. It can act as an inhibitor of late-stage cancer due to its anti-angiogenic effects [136].

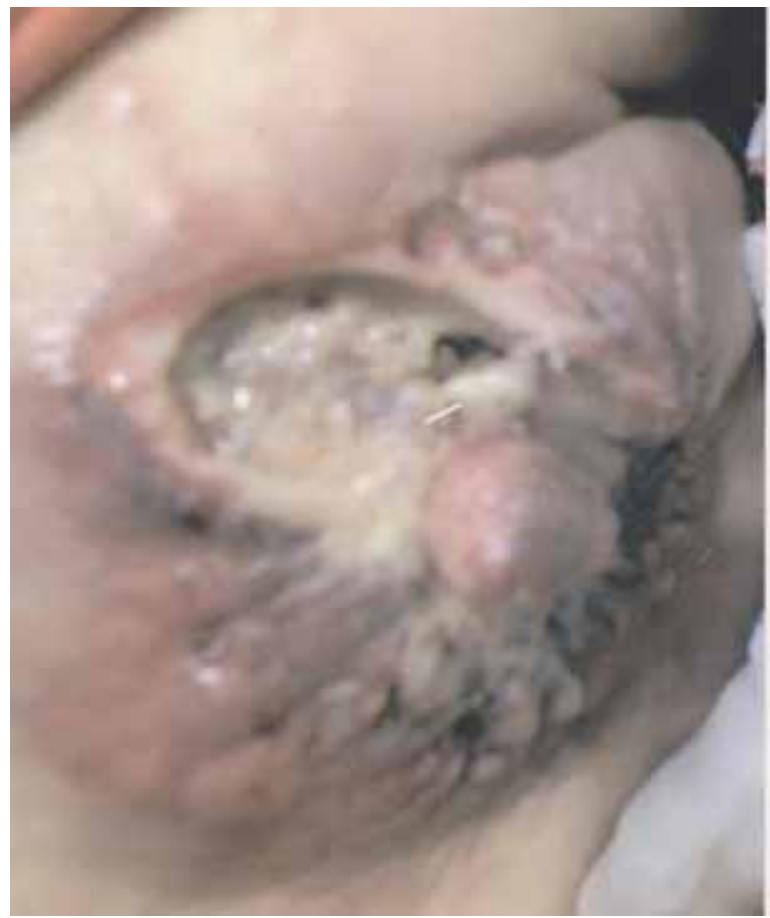

Figure 1: Photograph taken approximately a month prior to cessation of phyto-nutritional therapy showing the last of several malignant lumps that disintegrated, with minimal inflammation around open wounds.

\subsection{Green Tea Polyphenols (Standardized to $80 \%$ Epigallocatechin Gallate or EGCG)}

500mg TID. EGCG is a well-researched [137, 138] constituent of green tea polyphenols which induces apoptosis and cell cycle arrest in breast and many other cancer cell lines without affecting normal cells [139]. It exerts inhibitory effects on diverse cellular events associated with multi-stage carcinogenesis [140]. It can inhibit neovascularization promoted by VEGF in breast and other cancer cell lines [137, 141, $142]$, as well as blocking pathways involving nuclear factor-kappaB (NFkB), MMPs, and COX-2, which are implicated in tumor cell growth and survival [121, 122]. EGCG is a potent pro-apoptotic agent in estrogendependent MCF-7 breast cancer cells that targets survivin expression via suppression of the Protein Kinase B (PKB)/AKT pathway [143], which alterations have been detected in a number of human malignancies [144]. It is chemopreventive in breast carcinoma especially with over-expression of fatty acid synthase enzyme [145].

\section{CONTROVERSIES ON USE OF MULTIVITAMINS}

More than $50 \%$ of cancer patients might have micronutrient intakes below the recommended daily allowance (RDA) levels from food alone [146]. Nutrients with strong antioxidant properties such as vitamins $C$ and $E$, alpha lipoic acid, beta carotene, and selenium can reduce free radical loads widely implicated in numerous chronic health disorders including BC. Cellular deoxyribonucleic acid (DNA) mutation is a critical step in carcinogenesis and excessive oxidative DNA lesions have been observed in many tumour types, implicating such damage in the etiology of cancer [147]. In the US Women's Healthy Eating and Living Study, 58\% of the BC survivors reported use of multivitamins with $46 \%$ and $42 \%$ reporting use of vitamins $E$ and $C$, respectively [148, 149]. However, a diagnosis of cancer may not, by itself, lead to supplement use [150].

A Swedish study found that for women consuming less than 5 grams alcohol/day the use of multivitamin was associated with a $19 \%$ increased risk of BC compared with women not taking these vitamins [151]. On the other hand, the US Nurses' Health Study found that the use of multivitamins was associated with a lower risk of $\mathrm{BC}$ among women with high-alcohol consumption [152]. Frequent intake of excessive carotenoids may be linked to higher risk of $B C$ death [153] although supplemented vitamins C, D, E, or B-6 is not associated with $\mathrm{BC}$ risk. However, most studies have showed a decreased risk of death for those with higher intakes of beta-carotene and vitamin C [45, 109, 110]; others reported a similar effect but the findings were insignificant $[154,155]$. While some reported no association between individual micronutrients and allcause mortality risk $[156,157]$ or between multivitamin use and $B C$ risk [158, 159], multivitamin use was found to reduce risk for women who regularly consume alcohol or to decrease risk of ER- and progesterone receptor negative BC [160].

Vitamin supplementation in the first six months after $\mathrm{BC}$ diagnosis might be associated with reduced risk of mortality and recurrence [119]. Although low folate levels seem to be associated with a higher risk of cancer development [161, 162], it is being argued that synthetic folic acid in multivitamin supplements may promote malignancy [163] since its increasing serum concentrations can lead to a dose-dependent downregulation of tumor suppressor genes promoting increased DNA methylation in non-invasive MCF-7 breast cells [164]. Controversies may apply equally to 
high intake of vegetables, fruits and fiber and low fat diet where it was observed that survivors of early stage $\mathrm{BC}$ who adopted such a diet did not reduce subsequent BC events or mortality [165].

\section{MALNUTRITION}

Malnutrition can be a decisive factor in the overall treatment outcome for cancer patients [166]. It is a major cause of cancer morbidity and mortality [167] and its adverse consequences include impairment of immune functions, muscular function, and quality of life (QoL). There is strong association between diet and prognostic factors [2, 168, 169]. Nutrition-related diseases have emerged as the major health threat [170]. More aggressive cancers seem to be more prevalent in nutritional deficiency status in $85 \%$ of undernourished patients [166].

The incidence of malnutrition in cancer patients may be up to $80 \%[171,172]$ depending on stage of disease, treatment received and the types of nutritional assessment method used [173]. Cancer cachexia (characterized by weight loss and muscle wasting) contributes to malnutrition [172] and low quality protein intake can lead to a lower physical functioning [174]. QoL depends on patient's health status, which is substantially influenced by nutritional factors [175]. While nutritional therapy for cancer is of acknowledged importance [176-178] and a key determinant of patient's QoL [179], higher body mass index (BMI) may be negatively correlated with QoL [180].

\section{CANCER APOPTOSIS}

Apoptosis is caspase-induced programmed cell death [181] which is an essential physiological process [182] that plays a critical role in the maintenance of healthy tissues and organ systems by providing a controlled cell deletion and avoiding uncontrolled cell proliferation [183]. The mechanism of action of many anticancer drugs is also based on their ability to induce apoptosis [184]. Several natural chemopreventive agents are known to possess strong cancer-preventive properties that could interrupt different stages of cancer $[139,183,185]$. Anti-apoptotic protein survivin is overexpressed in many human cancers including breast [186]. Phytonutrients that decrease the expression of this protein are crucial to surviving late stage BC.

\section{DIAGNOSTIC ISSUES}

Globally, more than one million women are diagnosed with BC every year [187]. Lactation seems to protect against BC at all ages [188]. Mammography screening can have several drawbacks, and a major one being its tendency towards false positive and false negative results with all their potential psychosocial consequences to women [189]. In addition, screening mammography in women aged 40 to 49 years at average risk for $\mathrm{BC}$ may be ineffective in reducing their mortality [190]. The radiographic appearance of the breast on mammography can vary among women and it reflects the variations in their breast tissue composition [191]. Since the days of pioneering work [192] describing the differences in risk of BC associated with variations in the mammographic appearance, other qualitative and quantitative methods of measuring percent mammographic density (PMD) [193] have been applied to the assessment of PMD in relation to $B C$ risk. PMD is calculated by dividing the dense area by the total area and multiplying by 100 [194]. The BC risk associated with PMD does not differ by age, menopausal status, or ethnicity [195]. The PMD, at a given age, may also be highly heritable [196].

Weight of the patient was determined using a SECA floor scale with an incorporated stadiometer to measure height. Weight and height were then used to calculate patient's BMI (weight $[\mathrm{kg}] /$ height $\left[\mathrm{m}^{2}\right]$ ) and her obesity was determined by BMI higher than $30 \mathrm{~kg} / \mathrm{m}^{2}$ [197]. Percentage weight loss is a sensitive and specific tool that can screen and identify signs of malnutrition [178]. The patient's BMI scores improved dramatically from 30.2 to 23.7 , which was closer to the widely regarded ideal score of 22.5 (Table $\mathbf{1}$ ).

Patient-Generated Subjective Global Assessment (PG-SGA) is a validated and specific nutritional assessment tool in integrative oncology [171]. It classifies patient's nutritional status in three degrees: adequate, moderate undernutrition, or severe malnutrition [198]. A variation of PG-SGA was used and the patient was assessed to be suffering from "moderate undernutrition". Hand grip strength measured by dynamometry as a marker of nutritional status [199] was not carried out. However, anthropometric measurements [174] such as changes in weight, lean body mass, total bone density as well as biochemical parameters such as serum albumin were performed.

A monthly blood sample was taken and the patient's BC biomarkers tested include estradiol and insulin-like growth factor-I (IGF-1). The most common serum marker for breast tumor/cancer is carbohydrate antigen 
(CA) 15-3, which is expressed by breast carcinoma cells. However, during normal pregnancy this tumor marker could be elevated too [200]. CA15-3 changes may correlate closely with the clinical course of the disease in up to $90 \%$ of the antigen positive cases. Consequently, this marker is useful in the surveillance of BC patients although about one-third of the patients with metastatic BC may not show any significant increase in CA15-3 [201]. Patients with stage IV breast cancer not responding to conventional treatment might have antigen levels greater than $40 \mathrm{U} / \mathrm{ml}$ and these levels could correspond with the stage of BC [202]. Indeed, most patients with metastatic BC might have CA15-3 levels greater than $50 \mathrm{u} / \mathrm{ml}$ [203]. In this particular patient, her initial score was rather high at $179 \mathrm{U} / \mathrm{ml}$ (Table 1). This antigen may be a more sensitive marker than the equally popular marker Carcino-embryonic Antigen (CEA) for evaluating and monitoring $B C$ patients [204] and for those with metastatic BC [205]. Whereas any score higher than $5 \mathrm{ng} / \mathrm{ml}$ could suggest presence of malignancy, the patient's score was 52. The combination of CA15-3 with Tumor Polypeptide Antigen (TPA) might show improved sensitivity of both markers [206]. However, TPA testing was not ordered due to its expense. Although CA 27-29 marker appears to be at least as sensitive and specific as CA15-3 in BC patients [207], this test was unavailable.

The scalp hair trace heavy metal contents could be linked to cancer development [208, 209]. In view of the urgency in initiating a therapy as requested by the patient, this test was not performed.

The patient had never received any prior training in breast self-examination (BSE). A woman's desire to receive such BSE training might be influenced by her personal and social factors [210].

\section{CONCLUSION}

Gene-diet interactions in cancer have yet to be fully understood. However, diet and food are clearly modifiable environmental factors. Besides improving QoL, dietary factors seemed to be crucial in determining breast cancer reversal for this premenopausal woman. Her conditions at the end of the sixth month of therapy were rechecked at a local hospital as being free from malignancy. It was unclear in what ways "spontaneous regression", if any, could be partly responsible for reversing the malignancy. Although based on a single case, the results achieved in reversing this advanced stage metabolic disorder warrants further investigation involving larger number of women with similar level of breast malignancy.

\section{REFERENCES}

[1] Sarkar FH, Li Y. Cell signaling pathways altered by natura chemopreventive agents. Mutat Res 2004; 555: 53-64 http://dx.doi.org/10.1016/j.mrfmmm.2004.04.015

[2] Holm LE, Callmer E, Hialmar ML, Lidbrink E, Nilsson B, et al. Dietary habits and prognostic factors in breast cancer. J Natl Cancer Inst 1989; 81: 1218-23.

http://dx.doi.org/10.1093/jnci/81.16.1218

[3] Willett WC, Hunter DJ, Stampfer MJ, Colditz G, Manson J, et al. Dietary fat and fiber in relation to risk of breast cancer: an 8-year follow-up. JAMA 1992; 21; 268(15): 2037-44. http://dx.doi.org/10.1001/jama.1992.03490150089030

[4] Zhang CX, Ho SC, Cheng SZ, Chen YM, Fu JH, et al. Effect of dietary fiber intake on breast cancer risk according to estrogen and progesterone receptor status. Eur J Clin Nutr 2011; 65(8): 929-36. http://dx.doi.org/10.1038/ejcn.2011.57

[5] Bagga D, Ashley JM, Geffrey SP, Wang HJ, Barnard RJ, et al. Effects of a very low fat, high fiber diet on serum hormones and menstrual function. Implications for breast cancer prevention. Cancer 1995; 76(12): 2491-6.

http://dx.doi.org/10.1002/10970142(19951215)76:12<2491::AIDCNCR2820761213>3.0.CO;2-R

[6] Cotterchio M, Boucher BA, Kreiger N, Mills CA, Thompson LU. Dietary phytoestrogen intake-lignans and isoflavonesand breast cancer risk (Canada). Cancer Causes Control 2008; 19(3): 259-72.

http://dx.doi.org/10.1007/s10552-007-9089-2

[7] Pan A, Demark-Wahnefried W, Ye X, Yu Z, Li H, et al. Effects of a flaxseed-derived lignan supplement on $\mathrm{C}$ reactive protein, IL-6 and retinol-binding protein 4 in type 2 diabetic patients. Br J Nutr 2009; 101: 1145-9. http://dx.doi.org/10.1017/S0007114508061527

[8] Pan A, Sun J, Chen Y, Ye X, Li H, et al. Effects of a flaxseedderived lignan supplement in type 2 diabetic patients: a randomized, double-blind, cross-over trial. PLOS ONE 2007; 2: e1148. http://dx.doi.org/10.1371/journal.pone.0001148

[9] Rock CL, Demark-Wahnefried W. Nutrition and survival after the diagnosis of breast cancer: a review of the evidence. $J$ Clin Oncol 2002; 20(15): 3302-16.

http://dx.doi.org/10.1200/JCO.2002.03.008

[10] Yang PM, Tseng HH, Peng CW, Chen WS, Chiu SJ. Dietary flavonoid fisetin targets caspase-3-deficient human breast cancer MCF-7 cells by induction of caspase-7associaited apoptosis and inhibition of autophagy. Int $\mathrm{J}$ Oncol 2012; 40(2): 469-78.

http://dx.doi.org/10.3892/ijo.2011.1203

[11] Fu B, Xue J, Li Z, Shi X, Jiang BH, Fang J. Chrysin inhibits expression of hypoxia-inducible factor-1alpha through reducing hypoxia-inducible factor-1alpha stability and inhibiting its protein synthesis. Mol Cancer Ther 2007; 6: 220-6. http://dx.doi.org/10.1158/1535-7163.MCT-06-0526

[12] Fang J, Zhou Q, Liu LZ, Xia C, Hu X, et al. Apigenin inhibits tumor angiogenesis through decreasing HIF-1alpha and VEGF expression. Carcinogenesis 2007; 28: 858-64. http://dx.doi.org/10.1093/carcin/bgl205

[13] Hu XW, Meng D, Fang J. Apigenin inhibited migration and invasion of human ovarian cancer A2780 cells through focal adhesion kinase. Carcinogenesis 2008; 29: 2369-76. http://dx.doi.org/10.1093/carcin/bgn244 
[14] Zhang YF, Kang HB, Li BL, Zhang RM. Positive effects of soy isoflavone food on survival of breast cancer patients in China. Asian Pac J Cancer Prev 2012; 13(2): 479-82. http://dx.doi.org/10.7314/APJCP.2012.13.2.479

[15] Wu AH, Yu MC, Tseng CC, Pike MC. Epidemiology of soy exposures and breast cancer risk. Br J Cancer 2008; 98(1): 9-14.

http://dx.doi.org/10.1038/sj.bjc.6604145

[16] Zhu YY, Zhou L, Jiao SC, Xu LZ. Relationship between soy food intake and breast cancer in China. Asian Pac J Cancer Prev 2011; 12(11): 2837-40.

[17] Ziegler R, Hoover RN, Pike MC, Hildesheim A, Nomura A, et al. Migration patterns and breast cancer risk in AsianAmerican Women. JNCI 1993; 85(22): 1819-27. http://dx.doi.org/10.1093/jnci/85.22.1819

[18] Wu AH, Ziegler RG, Horn-Ross PL, Nomura AM, West DW, et al. Tofu and risk of breast cancer in Asian-Americans. Cancer Epidemiol Biomarkers Prev 1996; 5(11): 901-6.

[19] Zhang C, Ho SC, Lin F, Cheng S, Fu J, et al. Soy product and isoflavone intake and breast cancer risk defined by hormone receptor status. Cancer Sci 2010; 101(2): 501-7. http://dx.doi.org/10.1111/j.1349-7006.2009.01376.x

[20] Gardner CD, Chatterjee LM, Franke AA. Effects of isoflavone supplements vs. soy foods on blood concentrations of genistein and daidzein in adults. J Nutr Biochem 2009; 20(3): 227-34.

http://dx.doi.org/10.1016/j.jnutbio.2008.02.008

[21] Hanf V, Gonder U. Nutrition and primary prevention of breast cancer: foods, nutrients and breast cancer risk. Eur J Obstet Gynecol Reprod Biol 2005; 123(2): 139-49. http://dx.doi.org/10.1016/j.ejogrb.2005.05.011

[22] Rahman KW, Li Y, Wang Z, Sarkar SH, Sarkar FH. Gene expression profiling revealed survivin as a target of 3,3 'diindolylmethane-induced cell growth inhibition and apoptosis in breast cancer cells. Cancer Res 2006; 66(9): 4952-60. http://dx.doi.org/10.1158/0008-5472.CAN-05-3918

[23] Sundar SN, Kerekatte V, Equinozio CN, Doan VB, Bjeldanes $\mathrm{LF}$, et al. Indole-3-carbinol selectively uncouples expression and activity of estrogen receptor subtypes in human breast cancer cells. Mol Endocrinol 2006; 20(12): 3070-82. http://dx.doi.org/10.1210/me.2005-0263

[24] Ahmad A, Kong D, Sarkar SH, Wang Z, Banerjee S, et al. Inactivation of UPA and its receptor UPAR by 3,3'diindolylmethane (DIM) leads to the inhibition of prostate cancer cell growth and migration. J Cell Biochem 2009; 107(3): 516-27. http://dx.doi.org/10.1002/jcb.22152

[25] Clarke JD, Dashwood RH, Ho E. Multi-targeted prevention of cancer by sulforaphane. Cancer Lett 2008; 269(2): 291-304. http://dx.doi.org/10.1016/i.canlet.2008.04.018

[26] Pledgie-Tracy A, Sobolewski MD, Davidson NE. Sulforaphane induces cell type-specific apoptosis in human breast cancer cell lines. Mol Cancer Ther 2007; 6(3): 101321. http://dx.doi.org/10.1158/1535-7163.MCT-06-0494

[27] Khoo HM, Mohamed S. Flavonoid (myricetin, quercetin, kaempferol, luteolin, and apigenin) content of edible tropical plants. J Agric Food Chem 2001; 49(6): 3106-12. http://dx.doi.org/10.1021/jf000892m

[28] Zhou Q, Yan B, Hu X, Li XB, Zhang J, et al. Luteolin inhibits invasion of prostate cancer PC3 cells through E-cadherin. Mol Cancer Ther 2009; 8: 1684-91.

http://dx.doi.org/10.1158/1535-7163.MCT-09-0191

[29] Fang J, Zhou Q, Shi XL, Jiang BH. Luteolin inhibits insulinlike growth factor 1 receptor signaling in prostate cancer cells. Carcinogenesis 2007; 28: 713-23.

http://dx.doi.org/10.1093/carcin/bgl189
[30] Singhai R, Patil VW, Jaiswal SR, Patel SD, Tayade M, et al. $\mathrm{E}-\mathrm{Cadherin}$ as a diagnostic biomarker in breast cancer. N Am J Med Sci 2011; 3(5): 227-33. http://dx.doi.org/10.4297/najms.2011.3227

[31] Zhang SM. Role of vitamins in the risk, prevention, and treatment of breast cancer. Curr Opin Obstet Gynecol 2004; 16: $19-25$.

http://dx.doi.org/10.1097/00001703-200402000-00005

[32] Zhang SM, Willett WC, Selhub J, Hunter DJ, Giovannucci EL, et al. Plasma folate, vitamin B6, vitamin B12, homocysteine, and risk of breast cancer. J Natl Cancer Inst 2003; 95(5): 373-80.

\section{http://dx.doi.org/10.1093/jnci/95.5.373}

[33] Khoja KK, Shaf G, Hasan TN, Syed NA, Al-Khalifa AS, et al. Fenugreek, a naturally occurring edible spice, kills MCF-7 human breast cancer cells via an apoptotic pathway. Asian Pac J Cancer Prev 2011; 12(12): 3299-304.

[34] Taylor WG, Elder JL, Chang PR, Richards KW. Microdetermination of diosgenin from fenugreek (Trigonella foenum-graecum) seeds. J Agri Food Chem 2000; 48: 520610.

\section{http://dx.doi.org/10.1021/jf000467t}

[35] Srinivasan S, Koduru S, Kumar R, Venguswamy G, Kyprianou N, et al. Diosgenin targets Akt-mediated prosurvival signaling in human breast cancer cells. Int $\mathrm{J}$ Cancer 2009; 125: 961-7.

\section{http://dx.doi.org/10.1002/ijc.24419}

[36] Oyagbemi AA, Saba AB, Azeez OI. Capsaicin: a novel chemopreventive molecule and its underlying molecular mechanisms of action. Ind J Cancer 2010; 47: 53-8. http://dx.doi.org/10.4103/0019-509X.58860

[37] Lee SH, Krisanapun C, Baek SJ. NSAID-activated gene-1 as a molecular target for capsaicin-induced apoptosis through a novel molecular mechanism involving GSK3beta, C/EBPbeta and ATF3. Carcinogenesis 2010; 31: 719-28.

http://dx.doi.org/10.1093/carcin/bga016

[38] Yang KM, Pyo JO, Kim GY, Yu R, Han IS, et al. Capsaicin induces apoptosis by generating reactive oxygen species and disrupting mitochondrial transmembrane potential in human colon cancer cell lines. Cellular \& Molecular Biol Lett 2009; 14: 497-510. http://dx.doi.org/10.2478/s11658-009-0016-2

[39] Aggarwal BB. Targeting inflammation-induced obesity and metabolic diseases by curcumin and other nutraceuticals. Ann Rev Nutri 2010; 30: 173-99.

http://dx.doi.org/10.1146/annurev.nutr.012809.104755

[40] Kundu JK, Na HK, Surh YJ. Ginger-derived phenolic substances with cancer preventive and therapeutic potential. Forum Nutr 2009; 61: 182-92.

http://dx.doi.org/10.1159/000212750

[41] Dugasani S, Pichika MR, Nadarajah VD, Balijepalli MK, Tandra S, et al. Comparative antioxidant and antiinflammatory effects of [6]-gingerol, [8]-gingerol, [10]-gingerol and [6]-shogaol. J Ethnopharmacol 2010; 127: 515-20.

http://dx.doi.org/10.1016/.jep.2009.10.004

[42] Lee HS, Seo EY, Kang NE, Kim WK. [6]-Gingerol inhibits metastasis of MDA-MB-231 human breast cancer cells. J Nutr Biochem 2008; 19(5): 313-9. http://dx.doi.org/10.1016/j.jnutbio.2007.05.008

[43] Hoffman T. Ginger: an ancient remedy and modern miracle drug. Hawaii Medical J 2007; 66: 326-7.

[44] Tamimi RM, Hankinson SE, Campos $H$, Spiegelman D, Zhang S, et al. Plasma carotenoids, retinol, and tocopherols and risk of breast cancer. Am J Epidemiol 2005; 161(2): 15360 http://dx.doi.org/10.1093/aje/kwi030

[45] Ingram D. Diet and subsequent survival in women with breast cancer. Br J Cancer 1994; 69(3): 592-5.

http://dx.doi.org/10.1038/bjc.1994.108 
[46] Sato R, Helzlsouer KJ, Alberg AJ, Hoffman SC, Norkus EP, Comstock GW. Prospective study of carotenoids, tocopherols, and retinoid concentrations and the risk of breast cancer. Cancer Epidemiol Biomarkers Prev 2002; 11(5): 451-7.

[47] Shannon J, King IB, Moshofsky R, Lampe JW, Gao DL, et al. Erythrocyte fatty acids and breast cancer risk: a case-control study in Shanghai, China. Am J Clin Nutr 2007; 85: 1090-7.

[48] Kim J, Lim SY, Shin A, Sung MK, Ro J, et al. Fatty fish and fish omega-3 fatty acid intakes decrease the breast cancer risk: a case-control study. BMC Cancer 2009; 9: 216. http://dx.doi.org/10.1186/1471-2407-9-216

[49] Gago-Dominguez M, Yuan JM, Sun CL, Lee HP, Yu MC. Opposing effects of dietary $n-3$ and $n-6$ fatty acids on mammary carcinogenesis: The Singapore Chinese Health Study. Br J Cancer 2003; 89(9): 1686-92. http://dx.doi.org/10.1038/sj.bjc.6601340

[50] Goodstine SL, Zheng T, Holford TR, Ward BA, Carter D, et al. Dietary $(n-3) /(n-6)$ fatty acid ratio: possible relationship to premenopausal but not postmenopausal breast cancer risk in U.S. women. J Nutr 2003; 133(5): 1409-14.

[51] Alfano CM, Imayama I, Neuhouser ML, Kiecolt-Glaser JK, Smith AW, et al. Fatigue, inflammation, and $\omega-3$ and $\omega-6$ fatty acid intake among breast cancer survivors. $J$ Clin Oncol 2012; 30(12): 1280-7.

http://dx.doi.org/10.1200/JCO.2011.36.4109

[52] Serini S, Fasano E, Piccioni E, Cittadini AR, Calviello G. Differential anti-cancer effects of purified EPA and DHA and possible mechanisms involved. Curr Med Chem 2011; 18(26): 4065-75.

http://dx.doi.org/10.2174/092986711796957310

[53] Tisdale MJ. Cancer cachexia. Anticancer Drugs 1993; 4: 1525.

http://dx.doi.org/10.1097/00001813-199304000-00001

[54] Fearon KC, Von Meyenfeldt MF, Moses AG, Van Geenen R, Roy $A$, et al. Effect of a protein and energy dense N-3 fatty acid enriched oral supplement on loss of weight and lean tissue in cancer cachexia: a randomised double blind trial. Gut 2003; 52(10): 1479-86.

http://dx.doi.org/10.1136/gut.52.10.1479

[55] Hansen MV, Madsen MT, Hageman I, Rasmussen LS, Bokmand S, et al. The effect of Melatonin on depression, anxiety, cognitive function and sleep disturbances in patients with breast cancer. The MELODY trial: protocol for a randomised, placebo-controlled, double-blinded trial. BMJ Open 2012; 2(1): e000647.

http://dx.doi.org/10.1136/bmjopen-2011-000647

[56] Korner E, Bertha G, Flooh E, Reinhart B, Wolf R, et al. Sleep-inducing effect of L-tryptophane. Eur Neurol 1986; 25 Suppl 2: 75-81. http://dx.doi.org/10.1159/000116087

[57] Wurtman RJ, Anton-Tay F. The mammalian pineal as a neuroendocrine transducer. Recent Prog Horm Res 1969; 25: 493-522.

http://dx.doi.org/10.1016/B978-0-12-571125-8.50014-4

[58] Schernhammer ES, Giobbie-Hurder A, Gantman K, Savoie J, Scheib $R$, et al. A randomized controlled trial of oral melatonin supplementation and breast cancer biomarkers. Cancer Causes Control 2012; 23(4): 609-16. http://dx.doi.org/10.1007/s10552-012-9927-8

[59] Malina C, Frigo S, Mathelin C. Sleep and breast cancer: Is there a link? Gynecol Obstet Fertil 2013; 41(2): 105-9. http://dx.doi.org/10.1016/j.gyobfe.2012.12.008

[60] Lissoni P, Chilelli M, Villa S, Cerizza L, Tancini G. Five-year survival in metastatic non-small lung cancer patients treated with chemotherapy alone or chemotherapy and melatonin: a randomized trial. J Pineal Res 2003; 35: 12-5. http://dx.doi.org/10.1034/j.1600-079X.2003.00032.x
[61] Sigounas G, Anagnostou A, Steiner M. dl-alpha-tocopherol induces apoptosis in erythroleukemia, prostate, and breast cancer cells. Nutr Cancer 1997; 28(1): 30-5. http://dx.doi.org/10.1080/01635589709514549

[62] National Research Council Staff. Diet and health: Implications for reducing chronic disease risk. Washington, DC: National Academy of Education 1989: 376-9.

[63] Salonen JT, Salonen R, Lappetelainen R, Maenpaa PH, Alfthan $\mathrm{G}$, et al. Risk of cancer in relation to serum concentrations of selenium and vitamins $A$ and $E$ : matched case-control analysis of prospective data. Br Med J 1985; 290: 417-20.

http://dx.doi.org/10.1136/bmj.290.6466.417

[64] U.S. Department of Agriculture, Agricultural Research Service 2011. USDA National Nutrient Database for Standard Reference, Release 24. Nutrient Data Laboratory Home Page, http://www.ars.usda.gov/ba/bhnrc/ndl. Accessed: Dec 8, 2014.

[65] Schrauzer G. The nutritional significance, metabolism and toxicology of selenomethionine. Adv Food Nutr Res 2003: 47: 73-112.

http://dx.doi.org/10.1016/S1043-4526(03)47002-2

[66] Clark LC, Combs GF Jr, Turnbull BW, Slate EH, Chalker DK, et al. Effects of selenium supplementation for cancer prevention in patients with carcinoma of the skin: a randomized controlled trial. Nutritional Prevention of Cancer Study. JAMA 1996; 76: 1957-63. http://dx.doi.org/10.1001/jama.1996.03540240035027

[67] Weber C, Bysted A, Hłlmer G. The coenzyme Q10 content of the average Danish diet. Int J Vitam Nutr Res 1997; 67(2): 123-9

[68] Sylvester PW, Russell M, Ip MM, Ip C. Comparative effects of different animal and vegetable fats fed before and during carcinogen administration on mammary tumorigenesis, sexual maturation, and endocrine function in rats. Cancer Res 1986; 46(2): 757-62.

[69] Alshatwi AA. Catechin hydrate suppresses MCF-7 proliferation through TP53/Caspase-mediated apoptosis. $J$ Exp Clin Cancer Res 2010; 29: 167 http://dx.doi.org/10.1186/1756-9966-29-167

[70] Tin AS, Sundar SN, Tran KQ, Park AH, Poindexter KM, et al. Antiproliferative effects of artemisinin on human breast cancer cells requires the downregulated expression of the E2F1 transcription factor and loss of E2F1-target cell cycle genes. Anticancer Drugs 2012; 23(4): 370-9. http://dx.doi.org/10.1097/CAD.0b013e32834f6ea8

[71] Sundar SN, Marconett CN, Doan VB, Willoughby JA Sr, Firestone GL. Artemisinin selectively decreases functional levels of estrogen receptor-alpha and ablates estrogeninduced proliferation in human breast cancer cells. Carcinogenesis 2008; 29(12): 2252-8.

\section{http://dx.doi.org/10.1093/carcin/bgn214}

[72] Alkhalaf M. Resveratrol-induced apoptosis is associated with activation of p53 and inhibition of protein translation in T47D human breast cancer cells. Pharmacology 2007; 80: 134-43. http://dx.doi.org/10.1159/000103253

[73] Nguyen TH, Mustafa FB, Pervaiz S, Ng FS, Lim LH. ERK1/2 activation is required for resveratrol-induced apoptosis in MDA-MB-231 cells. Int J Oncol 2008; 33(1): 81-92. http://dx.doi.org/10.3892/ijo.33.1.81

[74] Shin MH, Holmes MD, Hankinson SE, Wu K, Colditz GA, et al. Intake of dairy products, calcium, and vitamin $\mathrm{D}$ and risk of breast cancer. J Natl Cancer Inst 2002; 94(17): 1301. http://dx.doi.org/10.1093/jnci/94.17.1301

[75] Rothkopf M. Fuel utilization in neoplastic disease: implications for the use of nutritional support in cancer patients. Nutr Supp 1990; 6: 14-6. 
[76] Collier B, Dossett LA, May AK, Diaz JJ. Glucose control and the inflammatory response. Nutr Clin Pract 2008; 23: 3-15. http://dx.doi.org/10.1177/011542650802300103

[77] Murff HJ, Shu XO, Li H, Yang G, Wu X, et al. Dietary polyunsaturated fatty acids and breast cancer risk in Chinese women: a prospective cohort study. Int J Cancer 2011; 128(6): 1434-41.

http://dx.doi.org/10.1002/ijc.25703

[78] Rose DP, Connolly JM, Rayburn J, Coleman M. Influence of diets containing eicosapentaenoic or eocasahexaenoic acid on growth and metastasis of breast cancer cells in nude mice. J Nat Cancer Inst 1995; 87(8): 587-92. http://dx.doi.org/10.1093/jnci/87.8.587

[79] Nissenson AR, Goodnough LT, Dubois RW. Anemia: not just an innocent bystander? Arch Intern Med 2003; 163(12): 1400-4.

http://dx.doi.org/10.1001/archinte.163.12.1400

[80] Sun L, Franco OH, Hu FB, Cai L, Yu Z, et al. Ferritin concentrations, metabolic syndrome, and type 2 diabetes in middle-aged and elderly Chinese. J Clin Endocrinol Metab 2008; 93: 4690-6.

http://dx.doi.org/10.1210/jc.2008-1159

[81] Zijp IM, Korver O, Tijburg LB. Effect of tea and other dietary factors on iron absorption. Crit Rev Food Sci Nutr 2000; 40(5): 371-98.

http://dx.doi.org/10.1080/10408690091189194

[82] Weinstein RE, Bond BH, Silberberg BK. Tissue ferritin concentration in carcinoma of the breast. Cancer 1982; 50: 2406-9.

http://dx.doi.org/10.1002/1097

0142(19821201)50:11<2406::AID-

CNCR2820501127>3.0.CO;2-S

[83] Wang W, Knovich MA, Coffman LG, Torti FM, Torti SV. Serum ferritin: past, present and future. Biochim Biophys Acta 2010; 1800(8): 760-9.

http://dx.doi.org/10.1016/j.bbagen.2010.03.011

[84] Torti SV and Torti FM. Iron and cancer: more ore to be mined. Nat Rev Cancer 2013; 13(5): 342-355.

http://dx.doi.org/10.1038/nrc3495

[85] Saquib J, Rock CL, Natarajan L, Saquib N, Newman VA, et al. Dietary intake, supplement use, and survival among women diagnosed with early stage breast cancer. Nutr Cancer 2011; 63(3): 327-33.

http://dx.doi.org/10.1080/01635581.2011.535957

[86] Lockwood K, Moesgaard S, Folkers K. Partial and complete regression of breast cancer in patients in relation to dosage of coenzyme Q10. Biochem Biophys Res Commun 1994; 199(3): 1504-8.

http://dx.doi.org/10.1006/bbrc.1994.1401

[87] Lockwood K, Moesgaard S, Yamamoto T, Folkers K. Progress on therapy of breast cancer with vitamin Q10 and the regression of metastases. Biochem Biophys Res Commun 1995; 6; 212(1): 172-7.

http://dx.doi.org/10.1006/bbrc.1995.1952

[88] Premkumar VG, Yuvaraj S, Vijayasarathy K, Gangadaran SG, Sachdanandam P. Effect of coenzyme Q10, riboflavin and niacin on serum CEA and CA 15-3 levels in breast cancer patients undergoing tamoxifen therapy. Biol Pharm Bull. 2007; 30(2): 367-70.

http://dx.doi.org/10.1248/bpb.30.367

[89] Schaars CF, Stalenhoef AF. Effects of ubiquinone (coenzyme Q10) on myopathy in statin users. Curr Opin Lipidol 2008; 19(6): 553-7.

http://dx.doi.org/10.1097/MOL.0b013e3283168ecd

[90] Bischoff-Ferrari HA, Shao A, Dawson-Hughes B, Hathcock J, Giovannucci E, et al. Benefit-risk assessment of vitamin D supplementation. Osteoporos Int 2010; 21(7): 1121-32. http://dx.doi.org/10.1007/s00198-009-1119-3
[91] Raimondi S, Johansson H, Maisonneuve P, Gandini S. Review and meta-analysis on vitamin $D$ receptor polymorphisms and cancer risk. Carcinogenesis 2009; 30(7): 1170-80.

http://dx.doi.org/10.1093/carcin/bgp103

[92] Chen P, Hu P, Xie D, Qin Y, Wang F, et al. Meta-analysis of vitamin $D$, calcium and the prevention of breast cancer. Breast Cancer Res Treat 2010; 121(2): 469-77. http://dx.doi.org/10.1007/s10549-009-0593-9

[93] Kostner K, Denzer N, Muller CS, Klein R, Tilgen W, et al. The relevance of vitamin $\mathrm{D}$ receptor (VDR) gene polymorphisms for cancer: a review of the literature. Anticancer Res 2009 ; 29(9): 3511-36.

[94] McCullough ML, Rodriguez C, Diver WR, Feigelson HS, Stevens VL. Dairy, calcium, and vitamin D intake and postmenopausal breast cancer risk in the Cancer Prevention Study II Nutrition Cohort. Cancer Epidemiol Biomarkers Prev 2005; 14(12): 2898-904.

http://dx.doi.org/10.1158/1055-9965.EPI-05-0611

[95] Lu L, Yu Z, Pan A, Hu FB, Franco OH, et al. Plasma 25hydroxyvitamin $\mathrm{D}$ concentration and metabolic syndrome among middle-aged and elderly Chinese individuals. Diabetes Care 2009; 32: 1278-83.

http://dx.doi.org/10.2337/dc09-0209

[96] Natarajan K, Singh S, Grunberger D, and Aggarwal BB. Caffeic acid phenethyl ester is a potent and specific inhibitor of activation of nuclear transcription factor NF-kappa B. PNAS 1996; 93 (17): 9090-5.

http://dx.doi.org/10.1073/pnas.93.17.9090

[97] Watabe M, Hishikawa K, Takayanagi A, Shimizu N, Nakaki T. Caffeic acid phenethyl ester induces apoptosis by inhibition of NFkappaB and activation of Fas in human breast cancer MCF-7 cells. J Biol Chem 2004; 279: 6017-26. http://dx.doi.org/10.1074/jbc.M306040200

[98] Vatansever SH, Sorkun K, Deliloglu I, Gurhan S, Ozdal-Kurt $\mathrm{F}$, et al. Propolis from Turkey induces apoptosis through activating caspases in human breast carcinoma cell lines. Acta Histochem 2010; 112(6): 546-56. http://dx.doi.org/10.1016/j.acthis.2009.06.001

[99] Watanabe MA, Amarante MK, Conti BJ, Sforcin JM. Cytotoxic constituents of propolis inducing anticancer effects: a review. J Pharm Pharmacol 2011; 63(11): 1378-86. http://dx.doi.org/10.1111/j.2042-7158.2011.01331.x

[100] Sawicka D, Car H, Borawska MH, Niklinski J. The anticancer activity of propolis. Folia Histochem Cytobiol 2012; 50(1): 2537.

http://dx.doi.org/10.5603/FHC.2012.0004

[101] Zhao Q, Zheng X, Jiang J, Zhou H, Hu P. Determination of ginsenoside $\mathrm{Rg} 3$ in human plasma and urine by high performance liquid chromatography-tandem mass spectrometry. J. Chromatogr B Analyt Technol Biomed Life Sci 2010; 878: 2266-73. http://dx.doi.org/10.1016/i.jchromb.2010.06.019

[102] Li Y, Wicha MS, Schwartz SJ, Sun D. Implications of cancer stem cell theory for cancer chemoprevention by natural dietary compounds. J Nutr Biochem 2011; 22(9): 799-806. http://dx.doi.org/10.1016/j.jnutbio.2010.11.001

[103] Mai TT, Moon J, Song Y, Viet PQ, Phuc PV, et al. Ginsenoside F2 induces apoptosis accompanied by protective autophagy in breast cancer stem cells. Cancer Lett 2012 28; 321(2): 144-53. http://dx.doi.org/10.1016/j.canlet.2012.01.045

[104] Chou CC, Yang JS, Lu HF, Ip SW, Lo C, et al. Quercetinmediated cell cycle arrest and apoptosis involving activation of a caspase cascade through the mitochondrial pathway in human breast cancer MCF-7 cells. Arch Pharm Res 2010; 33(8): 1181-91.

http://dx.doi.org/10.1007/s12272-010-0808-y 
[105] Chien SY, Wu YC, Chung JG, Yang JS, Lu HF, et al. Quercetin-induced apoptosis acts through mitochondrial- and caspase-3-dependent pathways in human breast cancer MDA-MB-231 cells. Hum Exp Toxicol 2009; 28(8): 493-503. http://dx.doi.org/10.1177/0960327109107002

[106] Nesaratnam K, Ambra R, Selvaduray KR, Radhakrishnan A, Reimann K, et al. Tocotrienol-rich fraction of palm oil affects gene expression in tumor resulting from MCF-7 cell inoculation in athymic mice. Lipids 2004; 39: 459-67. http://dx.doi.org/10.1007/s11745-004-1251-1

[107] Radhika M, Ghoshal N, Chatterjee A. Comparison of effectiveness in antitumor activity between flavonoids and polyphenols of the methanolic extract of roots of Potentilla. fulgens in breast cancer cells. J Complement Integr Med. 2012; 9: Article 24.

http://dx.doi.org/10.1515/1553-3840.1644

[108] Rocha A, Wang L, Penichet $M$, Martins-Green $M$. Pomegranate juice and specific components inhibit cell and molecular processes critical for metastasis of breast cancer. Breast Cancer Res Treat 2012; 136(3): 647-58. http://dx.doi.org/10.1007/s10549-012-2264-5

[109] Jain M, Miller AB, To T. Premorbid diet and the prognosis of women with breast cancer. J Natl Cancer Inst 1994; 86(18): 1390-7.

http://dx.doi.org/10.1093/jnci/86.18.1390

[110] Rohan TE, Hiller JE, McMichael AJ. Dietary factors and survival from breast cancer. Nutr Cancer 1993; 20(2): 16777.

\section{http://dx.doi.org/10.1080/01635589309514283}

[111] Bleys J, Navas-Acien A, Guallar E. Serum selenium levels and all-cause, cancer, and cardiovascular mortality among US adults. Arch Intern Med 2008; 168(4): 404-10. http://dx.doi.org/10.1001/archinternmed.2007.74

[112] Schrauzer GN, White DA, Schneider CJ. Cancer mortalities correlation studies, IV. Associations with dietary intakes of certain trace elements, notably selenium antagonist. Bioinorg Chem 1977; 7: 35-56.

http://dx.doi.org/10.1016/S0006-3061(00)80127-1

[113] Nowak B, Chimielnicka J. Relationship of lead and cadmium to essential elements in hair, teeth and nails of environmentally exposed people. Ecotoxicol Environ Saf 2000; 46: 265-74.

http://dx.doi.org/10.1006/eesa.2000.1921

[114] Hayers RB. The carcinogenicity of metals in humans. Cancer Causes and Control 1997; 8: 371-85. http://dx.doi.org/10.1023/A:1018457305212

[115] Alatise OI, Schrauzer GN. Lead exposure: a contributing cause of the current breast cancer epidemic in Nigerian women. Biol Trace Elem Res 2010; 136: 127-39. http://dx.doi.org/10.1007/s12011-010-8608-2

[116] Schrauzer GN. Interactive effects of selenium and chromium on mammary tumor development and growth in MMTVinfected female mice and their relevance to human cancer. Biol Trace Elem Res 2006; 109: 281-92. http://dx.doi.org/10.1385/BTER:109:3:281

[117] Lajous M, Lazcano-Ponce E, Hernandez-Avila M, Willett W, Romieu I. Folate, vitamin B6, and vitamin B12 intake and the risk of breast cancer among Mexican women. Cancer Epidemiol Biomarkers Prev 2006; 15(3): 443-8. http://dx.doi.org/10.1158/1055-9965.EPI-05-0532

[118] Ronco AL, de Stefani E, Aune D, Boffetta P, DeneoPellegrini $\mathrm{H}$, et al. Nutrient patterns and risk of breast cancer in Uruguay. Asian Pac J Cancer Prev 2010; 11(2): 519-24.

[119] Nechuta S, Lu W, Chen Z, Zheng Y, Gu K, et al. Vitamin supplement use during breast cancer treatment and survival: a prospective cohort study. Cancer Epidemiol Biomarkers Prev 2011; 20(2): 262-71. http://dx.doi.org/10.1158/1055-9965.EPI-10-1072
[120] Aggarwal BB, Van Kuiken ME, lyer LH, Harikumar KB, Sung $B$. Molecular targets of nutraceuticals derived from dietary spices: Potential role in suppression of inflammation and tumorigenesis. Exp Bio Med 2009; 234: 825-49.

http://dx.doi.org/10.3181/0902-MR-78

[121] Roomi MW, Monterrey JC, Kalinovsky T, Rath $M$, Niedzwiecki A. Comparative effects of EGCG, green tea and a nutrient mixture on the patterns of MMP-2 and MMP-9 expression in cancer cell lines. Oncol Reports 2010; 24: 74757.

\section{http://dx.doi.org/10.3892/or 00000917}

[122] Park IJ, Lee YK, Hwang JT, Kwon DY, Ho J, et al. Green tea catechin controls apoptosis in colon cancer cells by attenuation of $\mathrm{H} 2 \mathrm{O} 2$-stimulated $\mathrm{COX}-2$ expression via the AMPK signaling pathway at low-dose $\mathrm{H} 2 \mathrm{O} 2$. Ann NY Acad Sci 2009; 1171: 538-44.

http://dx.doi.org/10.1111/j.1749-6632.2009.04698.x

[123] Kunnumakkara AB, Diagaradjane $P$, Anand $P$, Harikumar $\mathrm{KB}$, Deorukhkar A, et al. Curcumin sensitizes human colorectal cancer to capecitabine by modulation of cyclin D1, COX-2, MMP-9, VEGF and CXCR4 expression in an orthotopic mouse model. Int J Cancer 2009; 125: 2187-97. http://dx.doi.org/10.1002/ijc.24593

[124] Yance DR, Sagar SM. Targeting angiogenesis with integrative cancer therapies. Integr Cancer Therapies 2006; 5: 9-29.

http://dx.doi.org/10.1177/1534735405285562

[125] Wargovich MJ, Morris J, Brown V, Ellis J, Logothetis B, et al. Nutraceutical use in late-stage cancer. Cancer Metastasis Rev 2010; 29(3): 503-10. http://dx.doi.org/10.1007/s10555-010-9240-5

[126] Park CH, Hahm ER, Park S, Kim HK, Yang CH. The inhibitory mechanism of curcumin and its derivative against beta-catenin/Tcf signaling. FEBS Lett 2005; 579(13): 296571.

http://dx.doi.org/10.1016/j.febslet.2005.04.013

[127] Shao ZM, Shen ZZ, Liu CH, Sartippour MR, Go VL, et al. Curcumin exerts multiple suppressive effects on human breast carcinoma cells. Int J Cancer 2002; 98(2): 234-40. http://dx.doi.org/10.1002/ijc.10183

[128] Kamat AM, Tharakan ST, Sung B, Aggarwal BB. Curcumin potentiates the antitumor effects of Bacillus Calmette-Guerin against bladder cancer through the downregulation of NFkappaB and upregulation of TRAIL receptors. Cancer Research 2009; 69: 8958-66. http://dx.doi.org/10.1158/0008-5472.CAN-09-2045

[129] Kang HJ, Lee SH, Price JE, Kim LS. Curcumin suppresses the paclitaxel-induced nuclear factor-kappa beta in breast cancer cells and potentiates the growth inhibitory effect of paclitaxel in a breast cancer nude mice model. Breast $\mathrm{J}$ 2009; 15: 223-9.

http://dx.doi.org/10.1111/j.1524-4741.2009.00709.x

[130] Sandur SK, Deorukhkar A, Pandey MK, Pabon AM, Shentu $\mathrm{S}$, et al. Curcumin modulates the radiosensitivity of colorectal cancer cells by suppressing constitutive and inducible NFkappaB activity. Int J Rad Oncol, Biol, Physics 2009; 75: 53442.

http://dx.doi.org/10.1016/j.jirobp.2009.06.034

[131] Lin SS, Lai KC, Hsu SC, Yang JS, Kuo CL, et al. Curcumin inhibits the migration and invasion of human A549 lung cancer cells through the inhibition of matrix metalloproteinase-2 and -9 and vascular endothelial growth factor (VEGF) Cancer Lett 2009; 285: 127-33. http://dx.doi.org/10.1016/j.canlet.2009.04.037

[132] Kakarala M, Brenner D, Korkaya $\mathrm{H}$, Cheng $\mathrm{C}$, Tazi K, et al. Targeting breast stem cells with the cancer preventive compounds curcumin and piperine. Breast Cancer Res Treat 2010; 122: 777-85. http://dx.doi.org/10.1007/s10549-009-0612-x 
[133] Jiao Y, Wilkinson IV, Di XM, Wang W, Hatcher $\mathrm{H}$ et al. Curcumin, a cancer chemopreventive and chemotherapeutic agent, is a biologically active iron chelator. Blood 2009; 113: 462-469.

http://dx.doi.org/10.1182/blood-2008-05-155952

[134] Guha P, Dey A, Sarkar B, Dhyani MV, Chattopadhyay S, et al. Improved antiulcer and anticancer properties of a transresveratrol analog in mice. J Pharmacol Exp Ther 2009; 328: 829-38.

http://dx.doi.org/10.1124/jpet.108.145334

[135] Lee HS, Ha AW and Kim WK. Effect of resveratrol on the metastasis of $4 \mathrm{~T} 1$ mouse breast cancer cells in vitro and in vivo. Nutr Res Pract 2012; 6(4): 294-300. http://dx.doi.org/10.4162/nrp.2012.6.4.294

[136] Uchiyama T, Toda K, Takahashi S. Resveratrol inhibits angiogenic response of cultured endothelial F-2 cells to vascular endothelial growth factor, but not to basic fibroblast growth factor. Biol \& Pharm Bull 2010; 33: 1095-100.

http://dx.doi.org/10.1248/bpb.33.1095

[137] Boehm K, Borrelli F, Ernst E, Habacher G, Hung SK, et al. Green tea (Camellia sinensis) for the prevention of cancer. Cochrane Database Syst Revs 2009: CD005004. http://dx.doi.org/10.1002/14651858.CD005004.pub2

[138] Sagar SM, Yance D, Wong RK. Natural health products that inhibit angiogenesis: a potential source for investigational new agents to treat cancer-Part 2. Curr Oncol 2006; 13: 1426.

[139] Khan N, Adhami VM, Mukhtar $\mathrm{H}$. Apoptosis by dietary agents for prevention and treatment of cancer. Biochem Pharmacol 2008; 76: 1333-9.

http://dx.doi.org/10.1016/..bcp.2008.07.015

[140] Surh YJ. Molecular mechanisms of chemopreventive effects of selected dietary and medicinal phenolic substances. Mutat Res 1999; 428(1-2): 305-27. http://dx.doi.org/10.1016/S1383-5742(99)00057-5

[141] Kato K, Long NK, Makita H, Toida M, Yamashita T, et al. Effects of green tea polyphenol on methylation status of RECK gene and cancer cell invasion in oral squamous cell carcinoma cells. Br J Cancer 2008; 99: 647-54.

http://dx.doi.org/10.1038/sj.bjc.6604521

[142] Shankar S, Ganapathy S, Hingorani SR, Srivastava RK. EGCG inhibits growth, invasion, angiogenesis and metastasis of pancreatic cancer. Frontiers Biosci 2008; 13: 440-52.

http://dx.doi.org/10.2741/2691

[143] Tang Y, Zhao DY, Elliott S, Zhao W, Curiel TJ, et al. Epigallocatechin-3 gallate induces growth inhibition and apoptosis in human breast cancer cells through survivin suppression. Int J Oncol 2007; 31: 705-11. Cheng JQ, Lindsley CW, Cheng GZ, Yang H, Nicosia SV. The Akt/PKB pathway: molecular target for cancer drug discovery. Oncogene 2005; 24: 7482-92. http://dx.doi.org/10.1038/sj.onc. 1209088

[145] Pan MH, Lin CC, Lin JK, Chen WJ. Tea polyphenol (-)epigallocatechin 3-gallate suppresses heregulin-beta1induced fatty acid synthase expression in human breast cancer cells by inhibiting phosphatidylinositol 3-kinase/Akt and mitogen-activated protein kinase cascade signaling. J Agric Food Chem 2007; 55: 5030-7. http://dx.doi.org/10.1021/jf070316r

[146] Sebastian RS, Cleveland LE, Goldman JD, Moshfegh AJ. Older adults who use vitamin/mineral supplements differ from nonusers in nutrient intake adequacy and dietary attitudes. $J$ Am Diet Assoc 2007; 107(8): 1322-32. http://dx.doi.org/10.1016/j.jada.2007.05.010

[147] Valko M, Rhodes CJ, Moncol J, Izakovic M, Mazur M. Free radicals, metals and antioxidants in oxidative stress-induced cancer. Chem Biol Interact 2006; 160(1): 1-40.

http://dx.doi.org/10.1016/j.cbi.2005.12.009
[148] Rock CL, Newman VA, Neuhouser ML, Major J, Barnett MJ. Antioxidant supplement use in cancer survivors and the general population. J Nutr 2004; 134: 3194-5.

[149] Newman V, Rock CL, Faerber S, Flatt SW, Wright FA, et al. Dietary supplement use by women at risk for breast cancer recurrence. The Women's Healthy Eating and Living Study Group. J Am Diet Assoc 1998; 98(3): 285-92.

http://dx.doi.org/10.1016/S0002-8223(98)00068-6

[150] Miller MF, Bellizzi KM, Sufian M, Ambs AH, Goldstein MS, et al. Dietary supplement use in individuals living with cancer and other chronic conditions: a population-based study. J Am Diet Assoc 2008; 108(3): 483-94.

http://dx.doi.org/10.1016/j.jada.2007.12.005

[151] Larsson SC, Akesson A, Bergkvist L, Wolk A. Multivitamin use and breast cancer incidence in a prospective cohort of Swedish women. Am J Clin Nutr 2010; 91(5): 1268-72. http://dx.doi.org/10.3945/ajcn.2009.28837

[152] Zhang S, Hunter DJ, Forman MR, Rosner BA, Speizer FE, et al. Dietary carotenoids and vitamins $A, C$, and $E$ and risk of breast cancer. J Natl Cancer Inst 1999; 91(6): 547-56. http://dx.doi.org/10.1093/jnci/91.6.547

[153] Greenlee H, Kwan ML, Kushi LH, Song J, Castillo A, et al. Antioxidant supplement use after breast cancer diagnosis and mortality in the Life After Cancer Epidemiology (LACE) cohort. Cancer. 2012; 118(8): 2048-58. http://dx.doi.org/10.1002/cncr.26526

[154] Fink BN, Gaudet MM, Britton JA, Abrahamson PE, Teitelbaum SL, et al. Fruits, vegetables, and micronutrient intake in relation to breast cancer survival. Breast Cancer Res Treat 2006; 98(2): 199-208. http://dx.doi.org/10.1007/s10549-005-9150-3

[155] Fleischauer AT, Simonsen N, Arab L. Antioxidant supplements and risk of breast cancer recurrence and breast cancer-related mortality among postmenopausal women. Nutr Cancer 2003; 46(1): 15-22.

http://dx.doi.org/10.1207/S15327914NC4601 02

[156] Holmes MD, Stampfer MJ, Colditz GA, Rosner B, Hunter DJ, et al. Dietary factors and the survival of women with breast carcinoma. Cancer 1999; 86(5): 826-35.

http://dx.doi.org/10.1002/(SICI)1097-

0142(19990901)86:5<826::AID-CNCR19>3.0.CO;2-0

[157] Saxe GA, Rock CL, Wicha MS, Schottenfeld D. Diet and risk for breast cancer recurrence and survival. Breast Cancer Res Treat 1999; 53(3): 241-53. http://dx.doi.org/10.1023/A:1006190820231

[158] Neuhouser ML, Wassertheil-Smoller S, Thomson C, Aragaki A, Anderson GL, et al. Multivitamin use and risk of cancer and cardiovascular disease in the Women's Health Initiative cohorts. Arch Intern Med 2009; 169: 294-304.

http://dx.doi.org/10.1001/archinternmed.2008.540

[159] Feigelson HS, Jonas CR, Robertson AS, McCullough ML, Thun MJ, et al. Alcohol, folate, methionine, and risk of incident breast cancer in the American Cancer Society Cancer Prevention Study II Nutrition Cohort. Cancer Epidemiol Biomarkers Prev 2003; 12: 161-4.

[160] Ishitani K, Lin J, Manson JE, Buring JE, Zhang SM. A prospective study of multivitamin supplement use and risk of breast cancer. Am J Epidemiol 2008; 167: 1197-206. http://dx.doi.org/10.1093/aje/kwn027

[161] Sellers TA, Vierkant RA, Cerhan JR, Gapstur SM, Vachon $\mathrm{CM}$, et al. Interaction of dietary folate intake, alcohol, and risk of hormone receptor-defined breast cancer in a prospective study of postmenopausal women. Cancer Epidemio Biomarkers Prev 2002; 11: 1104-7.

[162] Maruti SS, Ulrich CM, White E. Folate and one-carbon metabolism nutrients from supplements and diet in relation to breast cancer risk. Am J Clin Nutr 2009; 89: 624-33. http://dx.doi.org/10.3945/ajcn.2008.26568 
[163] Ulrich CM. Folate and cancer prevention: a closer look at a complex picture. Am J Clin Nutr 2007; 86: 271-3.

[164] Lubecka-Pietruszewska K, Kaufman-Szymczyk A, Stefanska $B$, Fabianowska-Majewska K. Folic acid enforces DNA methylation-mediated transcriptional silencing of PTEN, APC and RARbeta2 tumour suppressor genes in breast cancer. Biochem Biophys Res Commun 2013; 430(2): 623-8. http://dx.doi.org/10.1016/j.bbrc.2012.11.103

[165] Pierce JP, Natarajan L, Caan BJ, Parker BA, Greenberg ER, et al. Influence of a diet very high in vegetables, fruit, and fiber and low in fat on prognosis following treatment for breast cancer: the Women's Healthy Eating and Living (WHEL) randomized trial. JAMA 2007; 298(3): 289-98. http://dx.doi.org/10.1001/jama.298.3.289

[166] Chaves MR, Boleo-Tome C, Monteiro-Grillo I, Camilo M and Ravasco P. The Diversity of Nutritional Status in Cancer: New Insights. Oncologist 2010; 15(5): 523-30. http://dx.doi.org/10.1634/theoncologist.2009-0283

[167] Van Cutsem E, Arends J. The causes and consequences of cancer-associated malnutrition. Eur J Oncol Nurs 2005; 9 Suppl 2: S51-63.

http://dx.doi.org/10.1016/j.ejon.2005.09.007

[168] Verreault R, Risson J, Deschenes L, Ward F, Meyer F, et al. Dietary fat in relation to prognostic indicators in breast cancer. J. Natl Cancer Inst 1988: 80: 819-25. http://dx.doi.org/10.1093/jnci/80.11.819

[169] Ingram DM, Robert A, Nottage RM. Host factors and breast cancer growth characteristics. Eur. J. Cancer 1992: 28A: 1153-61. http://dx.doi.org/10.1016/0959-8049(92)90477-J

[170] Yan C, Xu L, Yong L, Dong X, Jing F, et al. Nutrition-related diseases, including type 2 diabetes, metabolic syndrome, obesity, cardiovascular diseases, and many types of cancers. Adv Nutr 2011; 2(5): 428-39. http://dx.doi.org/10.3945/an.111.000703

[171] Isenring E, Bauer J, Capra S. The scored Patient-generated Subjective Global Assessment (PG-SGA) and its association with quality of life in ambulatory patients receiving radiotherapy. Eur J Clin Nutr 2003; 57: 305-9.

http://dx.doi.org/10.1038/sj.ejcn.1601552

[172] Tong $H$, Isenring $E$, Yates $P$. The prevalence of nutrition impact symptoms and their relationship to quality of life and clinical outcomes in medical oncology patients. Support Care Cancer 2009; 17: 83-90.

http://dx.doi.org/10.1007/s00520-008-0472-7

[173] Bauer JD, Capra S, Ferguson M. Use of the scored PatientGenerated Subjective Global Assessment (PG-SGA) as a nutrition assessment tool in patients with cancer. Eur $\mathrm{J}$ Clin Nutr 2002; 56: 779-85.

http://dx.doi.org/10.1038/sj.ejcn.1601412

[174] Trabal J, Leyes P, Forga MT, Hervas S. Quality of life, dietary intake and nutritional status assessment in hospital admitted cancer patients. Nutr Hosp 2006; 21: 505-10.

[175] Marin Caro MM, Laviano A, Pichard C. Nutritional intervention and quality of life in adult oncology patients. Clin Nutr 2007; 26: 289-301.

http://dx.doi.org/10.1016/i.clnu.2007.01.005

[176] Isenring EA, Bauer JD, Capra S. Nutrition support using the American Dietetic Association medical nutrition therapy protocol for radiation oncology patients improves dietary intake compared with standard practice. J Am Diet Assoc 2007; 107: 404-12. http://dx.doi.org/10.1016/j.jada.2006.12.007

[177] Bauer JD, Capra S. Nutrition intervention improves outcomes in patients with cancer cachexia receiving chemotherapy: a pilot study. Supp Care Cancer 2005; 13: 270-4. http://dx.doi.org/10.1007/s00520-004-0746-7
[178] Ravasco P, Monteiro Grillo I, Marques Vidal P, Camilo M. Nutritional deterioration in cancer: the role of disease and diet. Clin Oncol 2003; 15: 443-50. http://dx.doi.org/10.1016/S0936-6555(03)00155-9

[179] Ravasco P, Monteiro-Grillo I, Vidal PM, Camilo ME. Cancer: disease and nutrition are key determinants of patients' quality of life. Support Care Cancer 2004; 12: 246-52. http://dx.doi.org/10.1007/s00520-003-0568-z

[180] Gil KM, Gibbons HE, Jenison EL, Hopkins MP, von Gruenigen VE. Baseline characteristics influencing quality of life in women undergoing gynecologic oncology surgery. Health Qual Life Outcomes 2007; 5: 25. http://dx.doi.org/10.1186/1477-7525-5-25

[181] Kerr JF, Wyllie AH, Currie AR. Apoptosis: a basic biological phenomenon with wide-ranging implications in tissue kinetics. Br J Cancer 1972; 26: 239-57.

http://dx.doi.org/10.1038/bjc.1972.33

[182] Zimmermann KC, Bonzon C, Green DR. The machinery of programmed cell death. Pharmacol Ther 2001; 92(1): 57-70. http://dx.doi.org/10.1016/S0163-7258(01)00159-0

[183] Khan N, Afaq F, Mukhtar H. Cancer chemoprevention through dietary antioxidants: progress and promise. Antioxid Redox Signal 2008; 10: 475-510. http://dx.doi.org/10.1089/ars.2007.1740

[184] Sen S, D'Incalci M. Biochemical events and relevance to cancer chemotherapy. FEBS Lett, 1992; 307, 122-7. http://dx.doi.org/10.1016/0014-5793(92)80914-3

[185] Surh YJ. Cancer chemoprevention with dietary phytochemicals. Nat Rev Cancer 2003; 3: 768-80. http://dx.doi.org/10.1038/nrc1189

[186] Foster FM, Owens TW, Tanianis-Hughes J, Clarke RB, Brenan $\mathrm{K}$ et al. Targeting inhibitor of apoptosis proteins in combination with ErbB antagonists in breast cancer. Breast Cancer Res 2009; 11(3): R41.

http://dx.doi.org/10.1186/bcr2328

[187] Coughlin SS, Ekwueme DU. Breast cancer as a global health concern. Cancer Epidemiol. 2009; 33(5): 315

http://dx.doi.org/10.1016/i.canep.2009.10.003

[188] World Cancer Research Fund, American Institute for Cancer Research. Food, nutrition, physical activity, and the prevention of cancer: a global perspective. Washington DC: Am Inst for Cancer Research; 2007.p290

[189] Primic-Zakelj M. Screening mammography for early detection of breast cancer. Ann Oncol 1999; 10 Suppl 6: 121-7. http://dx.doi.org/10.1093/annonc/10.suppl 6.S121

[190] Health Quality Ontario. Screening mammography for women aged 40 to 49 years at average risk for breast cancer: an evidence-based analysis. Ont Health Technol Assess Ser 2007; 7(1): 1-32.

[191] Johns PC, Yaffe MJ. X-ray characterisation of normal and neoplastic breast tissues. Phys Med Biol 1987; 32(6): 67595.

http://dx.doi.org/10.1088/0031-9155/32/6/002

[192] Wolfe JN. Risk for breast cancer development determined by mammographic parenchymal pattern. Cancer 1976; 37(5): 2486-92.

http://dx.doi.org/10.1002/1097-0142(197605)37:5<2486::AIDCNCR2820370542>3.0.CO;2-8

[193] Byng JW, Boyd NF, Fishell E, Jong RA, Yaffe MJ. The quantitative analysis of mammographic densities. Phys Med Biol 1994; 39(10): 1629-38. http://dx.doi.org/10.1088/0031-9155/39/10/008

[194] Boyd F, Martin LJ, Bronskill M, Yaffe MJ, Duric N et al. Breast tissue composition and susceptibility to breast cancer. J Natl Cancer Inst 2010; 102(16): 1224-37. http://dx.doi.org/10.1093/inci/dja239 
[195] Boyd NF, Guo H, Martin LJ, Sun L, Stone J, et al. Mammographic density and the risk and detection of breast cancer. N Engl J Med 2007; 356(3): 227-36. http://dx.doi.org/10.1056/NEJMoa062790

[196] Boyd NF, Martin LJ, Rommens JM, Paterson AD, Minkin S, et al. Mammographic density: a heritable risk factor for breast cancer. Methods Mol Biol 2009; 472: 343-60. http://dx.doi.org/10.1007/978-1-60327-492-0 15

[197] World Health Organization. Consultation on Obesity. Geneva: WHO; 1998.

[198] Ottery F. Definition of standardised nutritional assessment and interventional pathways in oncology. Nutrition 1996; 12: 15-9. http://dx.doi.org/10.1016/0899-9007(95)00067-4

[199] Norman K, Stobaus N, Zocher D, Bosy-Westphal A, Szramek $A$, et al. Cutoff percentiles of bioelectrical phase angle predict functionality, quality of life, and mortality in patients with cancer. Am J Clin Nutr 2010; 92: 612-9. http://dx.doi.org/10.3945/ajcn.2010.29215

[200] Han SN, Lotgerink A, Mhallen-Gziri M, van Calsteren K, Hanssens $\mathrm{M}$ et al. Physiologic variations of serum tumor markers in gynecological malignancies during pregnancy: a systematic review. BMC Med 2012; 10: 86. http://dx.doi.org/10.1186/1741-7015-10-86

[201] Schmidt-Rhode P, Schulz KD, Sturm G, Raab-Frick A, Prinz H. CA 15.3 as a tumour marker in breast cancer. Int $\mathrm{J}$ Biol Markers 1987; 2(3): 135-42.

[202] Colomer R, Ruibal A, Navarro M, Encabo G, Sole LA, et al. Circulating CA 15.3 levels in breast cancer: our present experience. Int J Biol Markers 1986; 1(2): 89-92.

[203] Barak V, Carlin D, Sulkes A, Treves A, Biran S. CA15-3 serum levels in breast cancer and other malignancies-correlation with clinical course. Isr J Med Sci. 1988; 24(9-10): 623-7.
[204] Hayes DF, Zurawski VR Jr, Kufe DW. Comparison of circulating CA15-3 and carcinoembryonic antigen levels in patients with breast cancer. J Clin Oncol 1986; 4(10): 154250.

[205] Tondini C, Hayes DF, Gelman R, Henderson IC, Kufe DW. Comparison of CA15-3 and carcinoembryonic antigen in monitoring the clinical course of patients with metastatic breast cancer. Cancer Res 1988; 48(14): 4107-12.

[206] Pectasides D, Pavlidis N, Gogou L, Antoniou F, Nicolaides C, et al. Clinical value of CA 15-3, mucin-like carcinomaassociated antigen, tumor polypeptide antigen, and carcinoembryonic antigen in monitoring early breast cancer patients. Am J Clin Oncol 1996; 19(5): 459-64. http://dx.doi.org/10.1097/00000421-199610000-00007

[207] Frenette PS, Thirlwell MP, Trudeau M, Thomson DM, Joseph $\mathrm{L}$, et al. The diagnostic value of CA 27-29, CA 15-3, mucinlike carcinoma antigen, carcinoembryonic antigen and CA 19-9 in breast and gastrointestinal malignancies. Tumour Biol. 1994; 15(5): 247-54. http://dx.doi.org/10.1159/000217898

[208] Piccinini L, Borella P, Bargellini A, Medici IC, Zoboli A. A case-control study on selenium, zinc, and copper in plasma and hair of subjects affected by breast and lung cancer. Biol Trace Elem Res 1996; 51: 23-30. http://dx.doi.org/10.1007/BF02790144

[209] Kilic E, Ozturk S, Demiroglu A, Yilmaz Z, Yildaz Z, et al. Analysis of element content in scalp hair of healthy people and breast cancer patients with SEM/EDX method. J NZ Med Assoc 2004; 117: 1-3

[210] Yang RJ, Huang LH, Shieh YS, Chung UL, Huang CS, et al. Motivations and reasons for women attending a breast selfexamination training program: A qualitative study. BMC Womens Health 2010; 10: 23. http://dx.doi.org/10.1186/1472-6874-10-23

\section{DOI: http://dx.doi.org/10.6000/1927-3037.2015.04.01.4}

(C) 2015 Steve Yap; Licensee Lifescience Global.

This is an open access article licensed under the terms of the Creative Commons Attribution Non-Commercial License (http://creativecommons.org/licenses/by-nc/3.0/) which permits unrestricted, non-commercial use, distribution and reproduction in any medium, provided the work is properly cited. 